\title{
A bloody war and a sickly season. The remarkable career of Admiral Sir Charles Edmund Kingsmill, RN ${ }^{1}$
}

\section{W.A.B. Douglas}

L'amiral Sir Charles Kingsmill, RN, a servi dans la Marine nationale de 1869 à 1920, un demi-siècle pendant lequel la Royal Navy a subi une révolution navale, la Marine royale canadienne a vu le jour, et la Première Guerre mondiale a été menée. En 1908, le premier ministre Laurier a invité Kingsmill à former un service naval à partir du ministère de la Marine et des Pêcheries. Kingsmill l'a accompli, et a réussi à survivre les difficultés engendrées par le défait de Laurier, à l'élection de 1911, par les conservateurs de Borden. Démuni de ressources au cours de la Première Guerre mondiale, et face à la catastrophe de l'explosion de Halifax en 1917, il a bricolé une défense navale suffisante pour répondre à la menace des sous-marins contre les convois dans l'Atlantique ouest. Reconnu pour ses services par l'Amirauté et par le gouvernement canadien, il a été anobli en 1918, mais lorsque tout effort pour mener à bien une expansion navale modeste après la guerre ont échoué, il a démissionné en 1920.

"The children of empire deserved a vision and have been given horse blinkers." D.M. Schurman, Imperial Defence, 1868-1887, edited by John Beeler (London: Frank Cass, 2000), author's introduction, p.1.

In 1908 the city of Quebec celebrated its 300th birthday. Among the dignitaries

1 This paper reflects the work of many others, especially Mike Kingsmill, of Brechin Ontario, who has given me access to papers and illustrations left to him by his grandfather Admiral Kingsmill and his father Charles Kingsmill, of Patti Kingsmill, who has given me access to similar material, of Dr Richard Gimblett, the Maritime Command historian of the Royal Canadian Navy, who first began research on Kingsmill and the origins of the Royal Canadian Navy in his master's thesis “'Tin-Pots' or Dreadnoughts? The Evolution of the Naval Policy of the Laurier Administration, 1896-1911" for Trent University in 1981, of Michael Hadley and Roger Sarty who built on this foundation with their Tin Pots and Pirate Ships: Canadian Naval Forces and German Sea Raiders, 1880-1918 (Montreal and Kingston: McGill-Queen's University Press, 1991), and of the official histories team led by Bill Johnston which produced The Seabound Coast: The Official History of the Royal Canadian Navy, 18671939, Volume I (Toronto: Dundurn, in cooperation with the Department of National Defence, 2010).

The Northern Mariner/Le marin du nord XXIV, No. 1 (January 2014), 41-63 
present - along with the Prince of Wales (the future King George V), and a squadron of the Royal Navy - was Sir Julian Corbett who, just having published his celebrated history of England and the Seven Years War, was an authority on the siege and capture of Quebec in 1759. Because he was also a trusted authority on contemporary naval matters, the Admiralty's director of naval intelligence (DNI) wanted him "to determine, quietly, see what military ... (especially naval) contributions Canada was prepared to make to the defence of the Empire as a whole." 2

The governor-general, (Lord Grey), General Sir Percy Lake, the British officer commanding the militia in Canada, and Rear-Admiral Charles Edmund Kingsmill, RN, in charge of the marine service of the Canadian marine and fisheries department, all spoke with Corbett. None of these gentlemen seemed to be in total agreement about Canadian capabilities and intentions, but as Captain Edmund Slade (DNI) observed in his report "Canada is a part of the Empire, and however bad they may be it would be the most fatal policy on our part to even hint that in time of danger we would abandon any part of it."3

Donald Schurman, in his biography of Corbett, caught a revealing glimpse of Admiral Kingsmill who, in a long conversation:

was very pessimistic ... (The) reservoir of, and facilities for, turning out competent officers were limited, and unhappily they were only available from the Lower Deck. There was a "total absence of any sense of discipline", and he supposed this impossible to inculcate without a fixed service system. The other discouraging feature was the prevalence of political patronage that was bound to frustrate the sound building of an officer corps. Concretely, he proposed introducing some permanence into the service, employing personnel for at least a three year period, and taking the climate into consideration by employing the hands in the dockyard in the winter. But he was clearly not hopeful and "seemed to feel all this (was) only a poor substitute for money contributions to the Royal Navy." 4

2 Captain Edmund Slade specified that this enquiry was to be made "as a service to Sir John Fisher", the First Sea Lord. Donald M. Schurman, Julian S. Corbett 1854-1922 (London: Royal Historical Society, 1981), 99. The relations between Slade and Fisher at this time have given rise to some discussion. Nicholas Lambert, in a hostile review of J.J. Widen's Theorist of Maritime Strategy: Sir Julian Corbett and his Contributions to Military and Naval Thought (Farnham, Surrey: Ashgate, 2012) argues that Slade and Fisher "clashed from virtually the first day", but this does not accord with Schurman's assessment of Corbett and Slade. See Lambert, "False Prophet?: The Maritime Theory of Julian Corbett and Professional Military Education," The Journal of Military History vol. 77, no.3 (July 2013), 1055-1078. Lambert acknowledges Schurman's unsurpassed understanding of Corbett, but suggests more recent scholarship has superceded Schurman. See also Nicholas Lambert, Fisher's Naval Revolution (Columbia, SC: University of South Carolina Press, 2002), 173177.

3 Schurman, Corbett, 111-2.

$4 \quad$ Ibid., 109; cf. Michael Whitby, “A Distance Beyond Geography: Canada and The Naval Review" in Peter Hore, ed., Dreadnought to Daring: 100 Years of Comment, Controversy and Debate in the Naval Review (Barnsley, U.K.: Seaforth, 2012) for British naval views on an autonomous Canadian navy, especially "Future of the Royal Canadian Navy," no. 3 
It was only two months since Kingsmill had received his promotion to rearadmiral, and accepted retirement from active service in the Royal Navy, in order to take up command of the Canadian government marine service, which included the patrol craft of the Fisheries Protection Service, and a fleet of lighthouse supply vessels, buoy tenders, icebreakers, and hydrographic survey ships. ${ }^{5}$ Although Canadian by birth, his thirty-nine years in the Royal Navy, and the knowledge he had of Corbett's views on naval matters, ${ }^{6}$ was likely to have influenced what he had to say. He must have known also that Corbett would report back to the Admiralty, and that the first sea lord, Admiral Sir John Fisher (with whom, as will be seen, Kingsmill may have been somewhat out of favour), would probably not have disagreed with his comments on the state of naval readiness in Canada. The first sea Lord needed to be on side, or at least in sympathy with him, if Kingsmill was to succeed in establishing the Canadian naval service decided upon by Sir Wilfrid Laurier and the minister of marine and fisheries, Louis-Philippe Brodeur.

Over the next two years, working with the deputy minister of the marine and fisheries department, Georges Desbarats, Kingsmill managed to create a new Department of the Naval Service, which took over some parts of the marine and fisheries department, and establish the Naval Service of Canada. On 4 May 1910 Parliament passed the Naval Service Act, on 4 August the Apollo class cruiser Rainbow was commissioned into the RCN, the Diadem class cruiser Niobe joined the service on 16 September, and in October the Royal Naval College of Canada opened in Halifax. On 21 October (an auspicious naval date that marks Horatio Nelson's defeat of the combined French and Spanish fleet in 1805), Niobe arrived in Halifax, and in November Rainbow arrived in Victoria, British Columbia. Nearly a year later, on 29 August 1911, the naval service, with royal assent, became the Royal Canadian Navy. ${ }^{7}$ This was perhaps the high point of Kingsmill's service in Canada. It is true that during ten subsequent and turbulent years in office he advanced to the rank of admiral (retired) in the Royal Navy, and in recognition of his war services from 1914-18 received a knighthood on the recommendations of both British naval authorities and the Canadian government. ${ }^{8}$ On the other hand, when he retired in 1920 it was because Prime Minister Robert Borden's Conservative Party caucus (possibly influenced by contradictory advice received from $\mathrm{RN}$ advisers over the previous six

(1915), 369, unsigned by Lieutenant-Commander H. B. Pilcher.

5 He was given six months to decide whether to take up the Canadian appointment, or return to active service in the RN; Kew, United Kingdom, The National Archives (hereafter, TNA), ADM 196/38. See also Charles D. Maginley and Bernard Collin, The Ships of Canada's Marine Services (St. Catharines, ON: Vanwell, 2001).

6 He had attended Corbett's lectures at the Naval College in Greenwich during the last four months of 1905, TNA, ADM 196/38.

7 Gilbert Norman Tucker, The Naval Service of Canada, Volume I: Origins and Early Years (Ottawa: King's Printer, 1952), 137; Desbarats to Undersecretary of State for External Affairs, 30 January 1911, Secretary to Governor-General, 16 August 1911: "His Majesty having been graciously pleased to authorize that the Canadian Naval Force shall be designated the 'Royal Canadian Navy,' this title is to be officially adopted, the abbreviation thereof being 'RCN'", Johnston et al., The Seabound Coast, 182.

8 TNA, ADM 196/38, p.755. 
years) had rejected every policy Kingsmill had put forward since the end of hostilities. As a final blow, the government decided in 1922 to close the naval college he had established in 1910. It was not until the eve of the Second World War, mainly thanks to his successor as director of the naval service and chief of naval staff Commodore Walter Hose, RCN, that the measures he had proposed in 1920 finally began to receive government approval. Kingsmill did not live to see the significant expansion, from six to some 450 ships, that took place after his death in $1935 .{ }^{9}$ Nevertheless, he is recognized as the "father" of the Royal Canadian Navy. ${ }^{10}$

Kingsmill's career until 1908 had been an epitome of mid- and late-Victorian developments in the Royal Navy. ${ }^{11}$ It was remarkable because, as a colonial with no high-ranking sponsors - he was never in the so-called "Fishpond" that marked the influence of Jacky Fisher on naval appointments before the First World War, nor was he a member of the elite in British society who "took considerable pride in being 'above' the ordinary," ${ }^{12}$ and on only two occasions had he won special recognition ${ }^{13}$ - he managed to do unusually well, and evidently established himself with some influential patrons, in a service where colonials were usually at a disadvantage. By 1891 he had won some important recognition in Canada as well. ${ }^{14}$

Precisely what lay behind Charles Kingsmill's entry into the Royal Navy cannot be documented. From the time that Charles' grandfather, William Kingsmill, had settled in the country, the Kingsmill family had been prominent in the political and military life

9 Johnston et al., The Seabound Coast, chapters 15 and 16. The destroyers Vancouver, Champlain, Skeena, and Saguenay, the sail training vessel Venture and the Battle Class trawler Armentieres were the only ships in commission at the time of Kingsmill's death, Ken Macpherson and Ron Barrie, Ships of Canada's Naval Forces, 1910-2002, 3rd edition (St. Catharines: Vanwell, 2002), 9-34.

10 "If any individual in the Department of the Naval Service can lay claim to Tucker's assertion of having 'more to do with the moulding of the service than any other man' that guiding hand ... clearly belonged to Kingsmill." Johnston et al., The Seabound Coast, 163; see Tucker, vol. I, 151, which gave the credit to Georges Desbarats.

11 Prior to the knighthood he received in 1918, Kingsmill had been awarded the African General Service Medal (bar Somaliland 1902-1904), Egypt Medal (1884-1885), Khedive's Star for service in Egypt, Grand Officer, Order of the Crown of Italy, Officer, Legion of Honour (France) (1906). See also http://en.wikipedia.org/wiki/Charles_Kingsmill, Medals of Admiral Sir Charles Edmund Kingsmill, Kt.

12 Robert L. Davison, The Challenges of Command: The Royal Navy's Executive Branch Officers 1880-1919 (London: Ashgate, 1911), 61; Nicholas Rodger, "Officers, Gentlemen and their Education, 1793-1860", in E. Freeman, ed., Les empires en guerre et paix: Journées Franco-Anglaises d'histoire de la Marine, Portsmouth 23-26 Mars 1988 (Vincennes: Service historique de la marine, 1990).

13 See notes 25 AND 31, below, TNA, ADM 196/38.

14 J. Hampden Burnham, Canadians in the Imperial Naval and Military Service (Toronto, 1891). Kingsmill is given a full page in this book, compared to the one or two lines devoted to his Canadian contemporaries in the navy. 
of Upper Canada. ${ }^{15}$ The family had connections in Britain that may have helped his candidacy for a cadet training establishment in England, but one is led to wonder why, when prospects appeared so favourable in Canada, Charles embarked on a life that would be far removed from the world he had been born into.

Certain events of his early life suggest how this happened. When he was five years old his mother, Ellen Diana Grange Kingsmill, was killed in a tragic sleighing accident, and his father subsequently remarried, three more times, ${ }^{16}$ which no doubt had a bearing on the boy's future. When old enough, he went to Upper Canada College, the most prestigious school in the province, as his father had done before him, but only

15 His father was a prominent lawyer and businessman in Upper Canada, Crown Attorney of Wellington Country at the time of Charles' birth. See “John Juchereau Kingsmill,"Henry J. Morgan, The Canadian Men and Women of the Time (Toronto: William Briggs, 1898). Family trees indicate that the Kilkenny branch of the Kingsmill family had its origins in England during the twelfth century, and Ireland in the sixteenth century, and that Charles Kingsmill's father, John Juchereau, born in Quebec 21 May 1829, the seventh of Captain William Kingsmill's nine children, was the first to be born in Canada. Captain Kingsmill (1793-1876) served in the 66 ${ }^{\text {th }}$ Regiment of Foot from 1815 to 1834 , in the Peninsular campaign, on the Island of St. Helena overseeing the exile of Napoleon until his death in 1821, in Ireland, and, from 1827 to 1834 , in the Canadas. He may have been encouraged to sell out by Lieutenant-Governor Sir John Colborne, who had been his commanding officer in the Peninsular campaign. Family records state "He was appointed by Sir John Colborne, afterwards Lord Seaton, the then Governor of Upper Canada, and under whom he had served in the War, to an office under the Provincial government, he was [according to Kingsmill's eldest daughter, Helena Maria Grange, mother of Lavinia Maude Grange] private secretary to Colborne, and continued there until an order was received from Sir Francis Bond Head directing him to proceed to Toronto with all the men he could muster to assist in the suppression of the rebellion ... in $1837 \ldots$ He raised, organized, drilled and brought into the field three regiments in succession, the discipline of which was approved of in a marked manner by the Commander of the Forces of the Niagara Frontier." With the rank of lieutenant-colonel he commanded the $3^{\text {rd }}$ Incorporated Militia of Upper Canada until appointed by Sir George Arthur to the shrievalty of the Niagara District, continuing in that office for twenty one years, He then "accepted the Post Mastership of Guelph, which office he held at the time of his death," Lavinia Maude Grange, "Memorandum respecting the Life of Lieut-Colonel William Kingsmill, compiled by his Grand-daughter L.M.G. Kingsmill, corrected and updated copy, privately published, 1906." F.H. Armstrong, Upper Canadian Chronology and Territorial Legislation (London, ON: University of Western Ontario Centennial publication, 1967), 181 confirms the appointment as sheriff of the Niagara District in 1840.

16 Letter from Woodlawn Park cemetery to Patti Kingsmill. Just before burial the body apparently moved, resulting in delay of the ceremony until it was quite certain that the lady had in fact deceased, Elora Observer, February 1860. See also Henry J. Morgan, The Canadian Men and Women of Our Time, $2^{\text {nd }}$ ed. (Toronto: William Briggs, 1912), "John Juchereau Kingsmill," who had two children by Ellen Diana Grange, four by Julia Dickson (one of whom died in infancy), whom he married in 1861, three by Caroline Stokes, whom he married in 1871 and three by Grace Bernard, whom he married in 1881. 
stayed there for a year. ${ }^{17}$ In 1867 , following the pattern of military service that so many among his close family and friends had performed, he went to a school in Brockville, Ontario run by Dr. Frederick W. Barron, a former headmaster of Upper Canada College, as a "crammer" for prospective candidates wishing to enter British officer training establishments. ${ }^{18}$ On 24 September 1869, sponsored (as were all Canadian candidates) by the governor-general of Canada, he entered the Royal Navy as a cadet, and on 21 June 1871 was promoted Midshipman. This was the beginning of a varied and successful naval career. ${ }^{19}$ He acquired skills in seamanship subject to the exacting standards of the Victorian navy, and while serving in the Royal Yacht was promoted Lieutenant on 5 September $1877 .{ }^{20}$ Selected in 1879 to qualify as a torpedo lieutenant at the Royal Navy's new torpedo school, HMS Vernon, ${ }^{21}$ he did not qualify, and was denied permission to sit the exams a second time, but still received a favourable assessment from the school. ${ }^{22}$ He went on to serve from 1881 to 1885 as senior Lieutenant in a newly

17 The school, founded in 1829 by Sir John Colborne, William Kingsmill's former commanding officer during the Peninsular campaign of the Napoleonic wars, provided a firm grounding for university and the professions. John Juchereau Kingsmill, who had attended UCC himself, served on the Board of the school. He went on to graduate in law from Osgoode Hall, Kingsmill papers, family tree, St. Mark's Church, Niagara-on-the Lake.

18 C.B. Koester, "Charles Edmund Kingsmill (1855-1935) Genealogical Sketch," 9 March 1992, Ottawa, National Defence Headquarters, Directorate of History and Heritage (hereafter DHH), biographical file "C.E. Kingsmill”; Richard H. Gimblett, "Admiral Sir Charles E. Kingsmill: Forgotten Father," in Michael Whitby, Richard H. Gimblett and Peter Haydon, The Admirals: Canada's Senior Naval Leadership in the Twentieth Century (Toronto: Dundurn, 2006). Gimblett observes that Dr. Barron's son would become an active advocate for a Canadian navy and that his grandson J.A. Barron would be the first cadet to join CGS Canada, in the period leading up to the formation of a Canadian navy in 1910. See also Burnham, Canadians in the Imperial Naval and Military Service Abroad. Until the end of the Second World War there were still Canadians, some of them graduates of the Royal Military College, who served in the British in preference to Canadian armed forces.

19 Published recollections of naval officers who were not among the elite in the nineteenth century are difficult to find. For a junior officer's view of the service Autobiography of Montagu Burrows, Captain RN (London: Macmillan, 1908), although it predates Kingsmill by a full generation, is an illuminating picture of life in the early Victorian navy, which was doing much the same thing in Burrows' day as it was when Kingsmill was serving in gunboats between 1869 and 1892 .

20 At HMS Britannia in 1870 he received a first class in seamanship, second class in "study," TNA, ADM 196/353; on 18 April 1877 he received a third class certificate and stood second in a class of nine for the lieutenant's exam, National Maritime Museum Greenwich, Manuscript department.

21 Ibid. The torpedo training school was still in its infancy, and there was only a handful of qualified officers in the RN, John B. Hattendorf et al., British Naval Documents 1204-1960 (Aldershot: Scolar Press for the Navy Record Society, 1993), 697, 723-5.

22 "Failed qualifying course for torpedo Lt but worked well, steadily \& has very good knowledge of torpedo work which I hope he may have an opportunity of using for the good of the service," TNA, ADM 196/38. 
commissioned composite sail and steam gunboat, HMS Arab, ${ }^{23}$ on the East Indies station.

As Anthony Preston and John Major have observed, "When the steam gunboat came on the scene the Navy was already accustomed to acting as a world police force." 24 In August of 1884, Arab joined the naval forces sent to Suakin to support the doomed Gordon Relief expedition to Khartoum. ${ }^{25}$ Although not directly involved in the land operations, Kingsmill (as the secretary of the admiralty noted on his service record) "Acted as beachmaster at Aden and while so employed was appointed by the $\mathrm{CinC}$ at the request of HM Consul for the Somali Coast as Vice Consul at Zeila: approved as a temporary measure." ${ }^{26}$ Not for the last time, he was profiting from what naval officers, proposing the toast for Thursday night dinners, call "a bloody war and a sickly season."

Seizing such an opportunity so early in his career probably did him no harm, especially when, almost as soon as Arab returned to England in May 1885, he received a glowing assessment from his captain. ${ }^{27}$ Recommended for another gunboat, he joined HMS Cormorant, a six-gun screw sloop launched at Chatham in 1877, and went off on another long overseas commission, this time to the Pacific. Cormorant had attracted considerable attention from a somewhat bloody episode during her first commission; she had certainly been acting as "part of a world police force." 28 If such activities marked her

23 The tenth Arab was a four-gun screw gunboat, launched at Glasgow in 1874. She was of 720 tons, 660 horsepower, and 10.4 knots speed. Her length, beam, and draught were $150 \mathrm{ft}, 28$ $\mathrm{ft}$, and $14 \mathrm{ft}$, http://www.worldnavalships.com/r_n_gunboats.htm.

24 Anthony Preston and John Major, Send a Gunboat: A Study of the Gunboat and its Role in British Policy, 1854-1904 (London: Longmans.1967), 7.

25 The Gladstone government had reluctantly authorised the so-called Gordon relief expedition under Garnet Wolseley to lift the siege of Khartoum, and Suakin was the port in eastern Sudan from which supplies were to be sent to Wolseley's force on the Nile. Winston Churchill, The River War (London, 1892); Julian Symons, England's Pride (London, 1965), Preston and Major, Send a Gunboat, 138-40; Sir William Laird Clowes, The Royal Navy (London: Sampson Low, Marston, 1897-1903), vol. VII, 350-389.

26 TNA, ADM 196/33, p. 752; see also ArchNet digital library; L.P. Walsh, Under the Flag and Somali Coast Stories (London, 1900): "Since 1880 the British Acting First Assistant Resident in Aden, Captain Frederick Mercer Hunter... selected the Aden Second Assistant Resident, Langton Prendergast Walsh, who was a former Commander of the Aden Settlement Police to be a Vice-Consul and the British local commander in Somaliland. Walsh was given an appointment in Somaliland as the representative of His Highness the Khedive of Egypt. Hunter installed Walsh and his 40 Aden policemen in Berbera. Zeila, still being a Turkish Pashalic (an area governed by a Pasha of Turkey) was treated separately as a British Agency, and another "British officer [presumably this refers to Lieutenant Kingsmill] was posted there..."

27 Form S206, a standard performance assessment known in the navy as a "flimsy", held among others in the Kingsmill papers at Brechin. Ontario.

28 'In 1879 a boat's crew in the New Hebrides, belonging to the British trader 'Mystery' had been massacred. The 'Cormorant,' ... one of five ships, under Commodore John Crawford Wilson proceeded to the islands on a punitive expedition and inflicted severe punishment on the natives," http://www.worldnavalships.com/naval_sloops_htm; Preston and Major, Send a Gunboat, 7. The Illustrated London News published an illustration of Cormorant at the time. 
second commission in the Pacific they did not attract comparable attention, but her presence in that theatre was representative of another development, the first tentative signs of interdepartmental co-operation between the army and the navy in imperial defence. The Defence Committee, established in 1878 , had begun "to make the empire-wide, that is to say the 'imperial' nature of modern British defence, clear and of immediate importance." 29

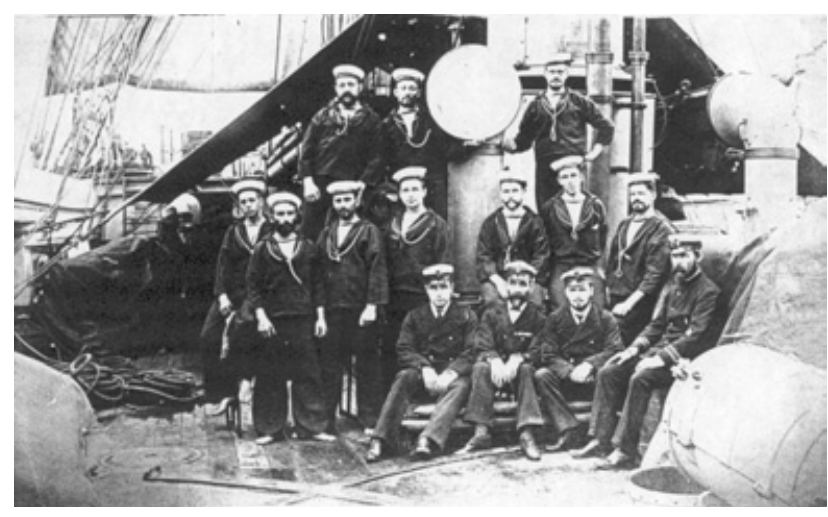

Illustration 1: Engine Room crew, HMS Cormorant; Kingsmill seated, middle of front row.

Circumstances during this commission favoured his career prospects in a remarkable fashion, taking advantage of a sickly season, if not this time of a bloody war. On the homeward passage his captain, Commander Jasper E.T. Nicholls, died of yellow fever. Kingsmill assumed command off Rio de Janeiro, and sailed the ship to Gibraltar. There the ship received "a very satisfactory report of inspection by Captain Buckle...Satisfaction of My Lords expressed to Lieut Kingsmill." ${ }^{30}$ He left Cormorant in Gibraltar, where she would soon be paid off, sailed to England, took 58 days foreign service leave and on 20 February 1890 assumed command of the newly commissioned gunboat HMS Goldfinch with the acting rank of commander. ${ }^{31}$

Goldfinch was sent to the Australian station. ${ }^{32}$ The ship touched a coral head in the Great Barrier Reef, on passage to Cooktown in Queensland, Australia, and he was "warned to be more careful," but he still received a satisfactory assessment. His

29 Donald M. Schurman, Imperial Defence 1868-1887 (ed John Beeler, London: Frank Cass, 2000), 55, 63, 71, 158.

30 The second classic example in his career of the British naval toast, TNA, ADM 196/38, p.752. The inspecting officer was Captain C.E. Buckle RN, senior officer in Gibraltar.

31 TNA, ADM 196/38, p.752. A member of the lower deck in Cormorant wrote to him: "On behalf of hands you left behind I have written to tell you that at last we have made shift towards going(?) home we were transferred here last Saturday evening before leaving the old Cormorant the senior officer informed us through Captain Chapman that he was very much pleased with the way we had conducted ourselves after you had left. We trust you had a pleasant passage \& that you arrived home safe. The Sultan arrived yesterday being(?) escorted by the Temeraire and we expect to leave here with her tomorrow. They are keeping us well at Gib on board here \& we are now holystoning their decks for them. This is about all we [can] tell you so will close hoping that you will receive yr promotion get a good ship \& spend as happy a commission as we have all done in the Old Cormorant. This is the sincere wish of the Unfortunate 19, from yrs respectfully G. Ralph,” Kingsmill papers, Brechin, Ontario. 
promotion to commander was confirmed, at the age of 36 , on 30 June $1891 .{ }^{33}$ It is indicative of service customs in 1891 that Kingsmill now felt at liberty to turn over command to his senior lieutenant and take several months leave. He landed on the island of Noumea, and eventually arrived in Toronto, Canada, travelling by way of Hawaii and California. ${ }^{34}$ As Robert Davison has suggested, "The very structure of the service helped to foster the illusion of officers being independent of the government that employed them." 35

The first real opportunity to see his father and his siblings since leaving home at the age of thirteen, this visit to Toronto was of considerable significance to his future life and career. The Kingsmills, particularly his father and uncle, had widened their circle of family friends and acquaintances, among whom the Beardmore family of Toronto were prominent. $^{36}$ Nicol Kingsmill, Charles' uncle, had strong imperialist leanings, and would become an active member of the Navy League of Canada after it was formed in 1895, and was providing certain legal services to Sir Wilfrid Laurier, who would be prime

33 TNA, ADM 53/13772, 19 August, 1890; Rear-Admiral Lord Charles Thomas Douglas Montague Scott who was then C-in-C of the Australian station had recommended him for advancement in January 1891, and although in April of that year he seems to have expressed some reservations: ("a hardworking and loyal officer but command is not quite his metier..."), his promotion went through. The Admiralty noted his proficiency in the French language and his "slight Arabic". ADM 196/38 loc.cit. He was in good company. John Rushworth Jellicoe, four years younger than Kingsmill, was promoted on the same day, in Jellicoe's case "through Captain Fisher's good offices," Admiral Sir R.H. Bacon, The Life of John Rushworth, Earl Jellicoe (London: Cassell, 1936), 59.

34 In Honolulu, according to his family papers, he visited the Hawaiian princess Kauilani. Seventeen years old in 1892, she would die at the age of twenty-four in 1899. The photographs in the Kingsmill collection include one which is autographed and dated 16 February 1892, evidence that she knew Kingsmill at a time when American businessmen and politicians were preparing to replace the Hawaiian monarchy with a new constitution.

35 Davison, Challenges of Command, 61. He applied for six months leave, granted on 5 November 1891, several months after leaving Goldfinch at Noumea, New Caledonia, $22^{\circ} \mathrm{S}$ $167^{\circ} \mathrm{W}$ - a desolate island at the time, but possibly the only convenient place for him to land, TNA, ADM 53/13772; note from Shipping Illustrated, "Retired from Goldfinch in 1891 and travelled for a period, visiting Honolulu, some of the western states, and reaching Toronto in 1892," Kingsmill Papers, Brechin, Ontario; " granted six months leave to remain in Canada \& arrived in England 17 Jan 1892,” TNA, ADM 196/38.

36 Possibly because Charles' cousin Walter Kingsmill provided certain legal services to the family. He was legal guardian to two boys in the family, who were apparently "of unsound mind", Ontario Legislative Assembly, Bills 1916, 2nd Session, 14th Legislature, vol. 1, no.191 (information from Ms Patti Kingsmill). Walter Dowker Beardmore of Toronto(1849 -1915) was the son of George Lissant Beardmore, who had prospered from his tanneries in Acton, and later in Bracebridge, Ontario, "The Beardmore One-Name Study" registered with the Guild of name studies, member no.222. Walter Beardmore was himself a highly successful business man, prominent in Toronto society, Morgan, Canadian Men and Women of the Time(1912); Constance's maternal grandfather was James Miller Williams, the man who first discovered oil in Sarnia, Ontario, Gary May, "Ontario's Living Dinosaur," The Beaver vol.88, no 3 (June-July 2008), 34-39. 
minister of Canada from 1896 to $1911 .^{37}$ Constance Beardmore and Charles Kingsmill, subsequent events suggest, may have come to an arrangement at this time that led to a most advantageous marriage some years later.

When Kingsmill returned to Britain in 1892 he reached a turning point in his career that more or less coincided with a turning point in the role of imperial defence in British naval policy. Donald Schurman, in his study of imperial defence from 1868-1887, points out that "The idea that Britain's defence was inextricably bound up with imperial defence as a whole was made clear in those early years, through reference to what later became only one part of the recognized requirements of a complete system of imperial defence." 38

Providentially, these had been the formative years in Kingsmill's professional life. It was a period when interdepartmental co-operation between the army and the navy had begun to take shape, at the instigation of the War Office. By the time Kingsmill began the transition from gunboats to capital ships in 1892, although the two services remained entities unto themselves, the process of growing interdependence had been at work for a decade or more. Consequently it was The Naval Defence Act of 1889, marking response to perceived British naval weakness, ${ }^{39}$ that created the framework in which his career now progressed. He attended Greenwich Naval College in $1892,{ }^{40}$ was appointed to HMS Victory for the dockyard reserve in November 1892, and spent a year there until appointed in October 1893 as commander (i.e. second in command) of the

37 "Mr. Kingsmill was a keen imperialist and, up to the time of his death, interested himself in Militia matters, serving on the frontier in 1866 on Col. Lowrie's staff at the time of the Fenian raid. Later in life he held a commission with the $10^{\text {th }}$ Royals, retiring with the rank of Captain ... "Such men as Mr Kingsmill and those of his class, of unblemished reputation and with high ideals of right and wrong, bring honour to our profession, and stand out as models for imitation by all who come after them; and, when they pass away, it may well be said of them that they have not lived in vain," Henry O'Brien, K.C., "In Remembrance of the late Nicol Kingsmill, K.C.," Canada Law Journal, 1 October 1912, copy in possession of Michael Kingsmill, Brechin, Ont.

38 Schurman, Imperial Defence, 152, 157. Political and military planners had been reacting to "the problem involved in the defence of a vast, mutually dependent, oceanic empire during a time of extensive naval technological change and comparatively slight international tension."

39 "Although the government had been reluctant to admit any naval deficiency hitherto, it had to reverse its attitude and, as with the Liberals in 1884, trim its sails to meet the breeze. Lord Salisbury, as he sadly admitted at the Guildhall in November, found himself compelled to enter England in the naval armaments race. In March 1889 the Naval Defence Act was introduced into Parliament. It provided for eight first-class battleships larger than any previously built - the Royal Sovereign class, the standard type of English battleship for ten years; 2 second-class battleships, 9 large and 29 smaller cruisers, 4 fast gunboats, and 18 torpedo-gunboats at a cost of $£ 21,500,000 \ldots . ., "$ Arthur Marder, The Anatomy of British Sea Power (London: Frank Cass, 1964), 143.

40 From February until September 1892 he was on half pay, but probably spent his time in private study at Greenwich until appointed to President for the naval college, TNA, ADM 196/38. 
armoured Orlando class cruiser HMS Immortalité of the Channel Squadron. Six months later the ship's officers transferred to the newly commissioned Blake class protected cruiser HMS Blenheim. ${ }^{41}$ It was while Kingsmill was serving in Blenheim that Canada's prime minister, Sir John Thompson, died during a visit to Windsor Castle in December 1894. The Admiralty recalled the ship from Gibraltar in order to convey Sir John Thompson's remains to Halifax. ${ }^{42}$

In September of the following year Kingsmill was appointed in command of

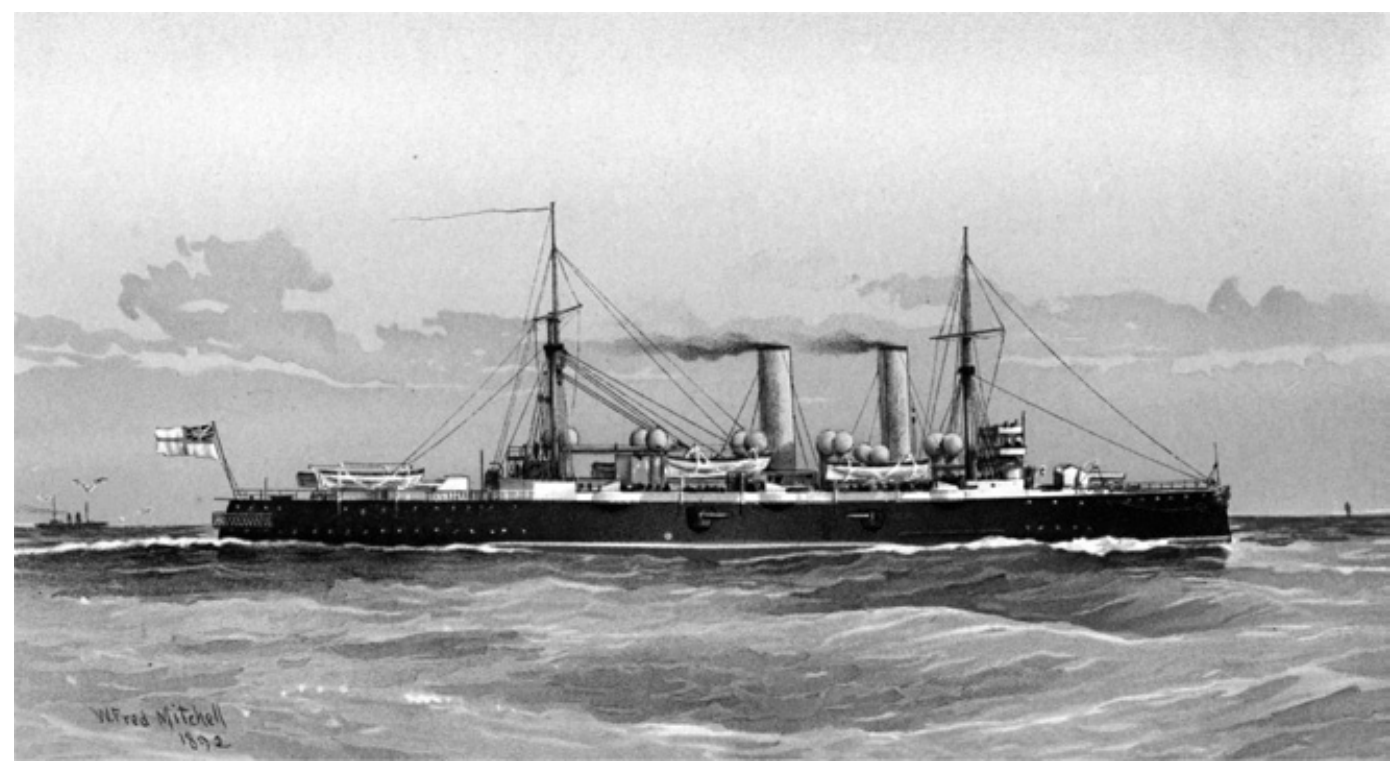

Illustration 2: HMS Blenheim, from a painting by W. Fred Mitchell. (Charles Rathbone Low, Her Majesty's Navy, Vol. III, London, J. S. Virtue \& Co., Limited, 1892.) Naval Marine Archive.

41 The Blake Class was an improvement on the Orlando Class, at a time of rapidly developing designs, between 1885 and 1899, Jane's Fighting Ships; "Blenheim... twin screw cruiser $1^{\text {st }}$ class, 9000 tons", with officers turned over from Immortalité, commissioned Chatham 26 May 94, Channel Squadron detached on special service," TNA, ADM 196/38.

42 Peter Waite, The Man from Halifax (Toronto: University of Toronto Press, 1985), 427-431. This was the first of three occasions that the ship carried out such services: "Blenheim served in the repatriation of the remains of three dignitaries during her career: His Royal Highness Prince Henry of Battenberg_died from malaria while on active duty onboard HMS Blonde off Sierra Leone in 1896. Blenheim repatriated his body from the Canary Islands. Her Majesty Queen Victoria appointed the commanding officer Captain Edmund S. Poe to the fourth class of the Royal Victorian Order as a mark of appreciation for this service. Sitting Canadian Prime Minister Sir John Thompson died in England, just after being named to HM Queen Victoria's Privy Council in 1894 and was repatriated to Halifax, Nova Scotia by Blenheim... Former Canadian Prime Minister Sir Charles Tupper died in England in 1915 and was repatriated to Halifax by Blenheim" http://en.wikipedia.org/wiki/HMS_Blen heim_(1890). 
HMS Archer, a torpedo cruiser stationed at Hong Kong. ${ }^{43}$ His service in Archer, although it coincided with growing tensions in China, ${ }^{44}$ was nevertheless uneventful. It concluded in November 1898 after a series of satisfactory inspections and recommendations for promotion. Vice-Admiral Sir Edward Seymour, the new commander of the China Station, commented in particular that Kingsmill was a good seaman, and on 31 December 1898, with his return to England, he was promoted Captain. ${ }^{45}$

For the best part of the next two years, partly on half pay and partly on various technical and professional courses, he remained ashore, until in September 1900 he was appointed in command of the Pearl class cruiser HMS Mildura, one of five acquired and paid for by Australia under the terms of the Imperial Defence Act of 1887. This reflects a certain pattern of employment. All his seagoing appointments until 1892 had been to ships east of Suez, and two of them - Cormorant and Goldfinch - had been among those serving in the imperial squadrons stationed in or near Australian waters. HMS Archer, although part of the China squadron, had given him increased familiarity with the region. He joined Mildura, a $3^{\text {rd }}$ class cruiser launched in 1889 as HMS Pelorus, and renamed in February 1890 for her first commission in the newly established Australian squadron. ${ }^{46}$

Kingsmill took up the appointment on his arrival in December 1900, having travelled by way of Toronto, where he married Constance Beardmore, who accompanied him to Australia. ${ }^{47}$ After an apparently uneventful commission he was recalled to England in November 1903, assuming command of HMS Scylla ${ }^{48}$ for the voyage from

43 One of eight $3^{\text {rd }}$ class protected cruisers laid down between 1885 and 1888, Jane's Fighting Ships.

44 In 1897 after a humiliating defeat by Japan, "Poor China...soon found out she had only been delivered from the hands of a single robber to fall into the hands of three bandits ... [Russia, Germany and France]," Bacon, Earl Jellicoe, 74-5. See also Marder, The Anatomy of British Sea Power, chapter14.

45 TNA, ADM 196/38

46 Colin Jones, Australian Colonial Navies (Canberra: Australian War Memorial, 1986), 116$128 ; 159$

47 Toronto Mail and Empire, 12 October 1900, 1 November 1900. See also St. George the Martyr, marriage register. The marriage, according to the newspaper announcement, took place at St. Andrews. Although not recorded in the St. Andrew by the Lake parish register, it is possible the ceremony may have taken place at this small church on Toronto Island, but been recorded by the priest in the register for his home parish, St. George the Martyr. Charles had been in New York in February 1900, during one of his periods on half pay, possibly staying with his sister Mrs J. Gault, and it seems very likely that he had been in touch with Constance Beardmore in Toronto to discuss marriage plans. Five days after Charles Kingsmill had sailed back to England, his father came to New York on his way to stay with two other daughters, Mrs Chester Glass and Mrs Langdon Wilks, in the Mediterranean, but died on passage. It is his obituary, which appeared in the New York Times, 27 February 1900, that reveals Charles' presence in New York.

48 An Apollo class second-class cruiser, built between 1889 and 1891. Kingsmill commanded her from 8 December 1903 to 16 February 1904. It was six years later that Kingsmill would advise the Canadian government to acquire Rainbow, an Apollo class cruiser of the same 
Australia. He then attended the signals, fleet tactics, and war courses in England in preparation for his January 1905 appointment in command of HMS Majestic, a preDreadnought battleship, lead ship of the Majestic class, first commissioned in 1895, and assigned to the Atlantic fleet in 1905. For a colonial in the Royal Navy this appointment reflected significant approval of his merits by a Naval Board which, headed by Admiral of the Fleet Lord Fisher, was embarking on a revolutionary course of scrapping obsolete and small vessels, and building up a fleet of large ships in home waters.

Circumstance and character appear at this moment to have favoured the fortunes of Captain Kingsmill. ${ }^{49}$ When the newly commissioned King Edward VII class of predreadnought battleships came into service, all except the lead ship named after regions of the British Empire, Kingsmill would be given command of the ship named for Canada, HMS Dominion. ${ }^{50}$ He joined on 28 March 1906, and that summer embarked on a flag waving cruise. At Quebec City, in August the Imperial Order of the Daughters of the Empire presented the ship with a magnificent collection of silver plate. ${ }^{51}$ There Kingsmill met Sir Wilfrid Laurier, ${ }^{52}$ at a time when the idea of a Canadian naval service, based on the patrol vessels of the Fisheries Protection Service, was gathering momentum. ${ }^{53}$ Laurier, who knew the family, and was aware that Charles' uncle Nicol had a prominent role in the Toronto branch of the Canadian Navy League, took an immediate liking to Charles Kingsmill, ${ }^{54}$ whose fortunes appeared to be in the ascendant, and so might they have been had he not blotted his copybook, on the way to Quebec, by putting his ship aground in Chaleur Bay.

Kingsmill had left the bridge when it appeared the ship was on a safe course to

vintage.

49 Constance Kingsmill, on this and future occasions, would appear not to have been backward in complementing the good impressions her husband was making on the great and famous. Kingsmill Papers, Brechin.

50 The others were all named after parts of the British Empire: Commonwealth, Dominion, Hindustan, New Zealand, Hibernia, Africa and Britannia, see Fred T. Jane, ed., Jane's Fighting Ships (London: Sampson, Low, Marston, 1906), 44. So far as I can determine, no other "colonials" were placed in command of these ships. In January 1906 Dominion, under the command of Captain John Marx, RN, had carried the remains of The Hon. Raymond Préfontaine, minister of marine and fisheries, after his sudden death in Paris, from Cherbourg to Halifax. When Captain Marx was promoted to rear-admiral on 6 March 1906 Kingsmill, no doubt in view of his Canadian interests, was selected to replace him.

51 This presentation was an expression of gratitude to HMS Dominion for returning the remains of Raymond Préfontaine to Canada in January 1906. See the Toronto Globe, 23 January 1906; Johnston et al., The Seabound Coast, 105-6. The collection of silver plate is now in the possession of the wardroom, HMCS Naden, at Esquimalt.

52 Laurier loaned several books of photographs to Mrs Kingsmill, accepted an invitation to dine on board, and was present for the presentation of silver plate by the Imperial Order of the Daughters of the Empire, Johnston et al., The Seabound Coast, 105-6.

53 Johnston et al., The Seabound Coast, 98-105.

54 O'Brien, "In Remembrance of the late Nicol Kingsmill, K.C.”; Gimblett "Admiral Sir Charles E. Kingsmill: Forgotten Father." 
clear the land in fine weather conditions, but the navigating officer mistook a forest fire ashore for a navigational light and fixed the position of the ship well clear of the land, when the tide and current were in fact setting the ship close inshore. Assured by messages from the bridge that the ship was on course, he captain was still at dinner when he felt the ship's movements as she touched ground. One can imagine his state of mind, and sympathise with the decisions he subsequently made. ${ }^{55}$

Dominion completed her schedule in Quebec before returning to England, after a visit to Bermuda dockyard for temporary repairs, and in March 1907 the captain, navigating officer and officer of the watch were brought before a court martial. As was to be expected the court, after acquitting the officer of the watch, found that the captain and navigating officer "did by default suffer His Majesty's Ship 'Dominion' to be stranded." That being said, no seaman can read the proceedings of this trial without compassion, nor without a measure of respect for the cool professionalism of Kingsmill and his ship's company, in the circumstances: ${ }^{57}$

The action of the Navigating Officer and the Officer of the Watch in putting the helm hard-a-port just before the ship took ground, caused her to slew to starboard to the Southward after touching. Boats were immediately lowered and soundings taken round the ship, the deepest water being off the starboard bow, and I steamed the ship off by going ahead as the tide rose. The boom boats were hoisted out to lighten the ship and to lay out anchors, if required, but this was not found necessary. The work ordered was carried out smartly by Officers and Ship's Company, and in a quiet and orderly manner. The work in the Engine Room Department was also particularly satisfactory. The ship was examined below and sounded, the only leak through the inner bottom shewed in the foremost stokehold where the oil fuel, which is stowed in the double bottoms, was forced up. The fires in this stokehold were drawn quietly to avoid any chance of accident. The Ship was then anchored for the night in $91 / 2$ fathoms. ${ }^{58}$

Kingsmill received a severe reprimand, but remained in command of Dominion,

55 Robert L. Davison, "A Most Fortunate Court Martial: The Trial of Captain Charles Kingsmill, 1907," The Northern Mariner/Le marin du nord vol. XIX (January 2009), 56-87.

56 TNA, ADM 1/7954, "Minutes of Proceedings of a Court Martial Held on H.M. Ship Acheron, 4-5 March 1907," pp. 127-129.

57 The writer, as a former Navigating Officer, recalls various unsettling incidents and sleepless nights when being prepared for the Long " $\mathrm{N}$ " course, and frequently required to conduct pilotage in dangerous waters, by a captain who had been the navigating officer of a ship, during the Second World War, which ended up on the rocks of Videy Island, in Reykjavik, Iceland, during a winter gale. On that occasion the navigating officer's advice not to anchor had been ignored, so that he was not court martialled: an example no doubt to be followed, if necessity demanded, which fortunately it never did, by his protégé!

58 TNA, ADM 1/7954. The sentence was too lenient in the opinion of the Board of Admiralty: "I concur in findings of ct martial [wrote the fourth sea lord] but I consider that both Captain and Lieut $\mathrm{N}$ both [should?] have been dismissed from HMS Dominion. " Fisher minuted: "Fully concur with the $4^{\text {th }}$ Sea Lord." It is more than likely that Kingsmill had friends in court! 
while the ship was undergoing repairs in Portsmouth, until 1 May 1907, when he went to Plymouth in command of the Royal Sovereign class battleship HMS Repulse, lying in Devonport with a nucleus crew as part of the reserve fleet.

To leave the recently commissioned Dominion for a somewhat older preDreadnought, in reserve, at the height of his career did not bode well for his future in the RN. It is interesting, however, that despite the opinion of Jacky Fisher and members of his board that Kingsmill should have been dismissed his ship, the Admiralty kept him on full pay, and that his new command was not without importance. Repulse, although in reserve, belonged to a division of special service ships in Devonport which, like similar divisions at Portsmouth and Chatham, were created as part of the First Sea Lord's preparation for war. Admiral of the Fleet Lord Fisher reminded the world in 1920 of his thinking in 1907:

The keystone of our preparedness for war has now to be inserted, namely, the provision of efficient nucleus crews.

This can be done to-morrow

A nucleus crew should consist of approximately two-fifths of her engine-room complement, the whole of her turret crews, gun layers and sight-setters for all guns, all important special ratings, and two-fifths of her normal crew, her captain, and all important officers. ${ }^{59}$

One did not arouse Fisher's disapproval without contemplating unfortunate consequences. However one regards it, the appointment to Repulse was not exactly a guarantee of continued favour. And even if Kingsmill went on to have favourable career prospects in the Royal Navy, his previous meetings with Prime Minister Laurier, and the family connections that reflected ties with the Liberal party in Canada, evidently gave a Canadian appointment added attraction. When Laurier and his new minister of marine and fisheries, Louis-Philippe Brodeur, arrived in England for the Colonial Conference of 1907, Kingsmill requested an interview with Laurier to assure him he was still in good standing with the Royal Navy. Laurier invited Captain and Mrs Kingsmill to dinner, and although we do not know what was said on that occasion, Kingsmill was clearly in good standing with the Canadian government. Nobody of comparable ability and experience, with such strong ties to Canada, was available to transform the Fisheries Protection Service into a naval force. One year later, on 1 May 1908, Governor-General the Earl

59 "Nucleus Crews. Two-yearly commissions to be instituted, and with no material change of officers and men during the two years. All the fighting vessels in Reserve to have an efficient nucleus crew of approximately two-fifths of the full crew, together with all the important Gunnery ratings as well as the Captain of the ship and the principal Officers. The periodical exercise and inspection of the ships by the responsible Flag Officer who will take them to the war. This Flag Officer will suffer for any want of efficiency and preparation for war of these vessels. These vessels to be collected in squadrons at Portsmouth, Plymouth and Chatham, according to the Station to which they are going as reinforcements." Lord Fisher, Memories and Records, Volume II, Records (New York, George H. Doran Co., 1920), 145-6. See also Lambert, Sir John Fisher's Naval Revolution, 158-161 for the failure of so many contemporary observers, army and navy, to understand the logic behind nucleus crews. 


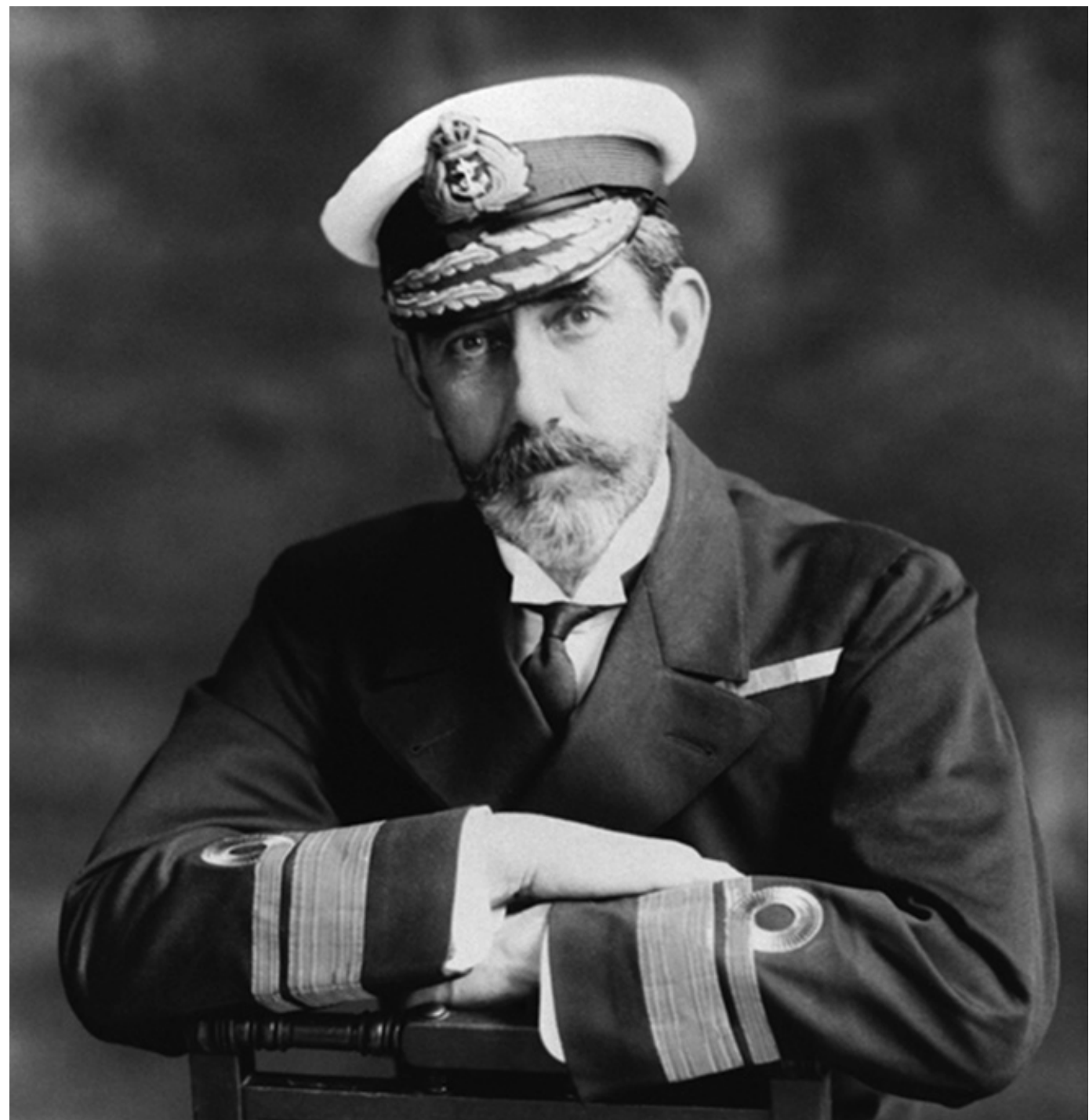

Illustration 3: Rear Admiral Kingsmill, circa 1910.

Grey informed Lord Tweedmouth, the first lord of the admiralty, that the Canadian government wanted Kingsmill to take charge of the Canadian Marine Service. Eleven days after that, on 12 May 1908, Kingsmill received a promotion to rear-admiral and left Repulse for his new command in Canada. ${ }^{60}$

This sequence of events suggests that at least as early as 1906, possibly even earlier, recalling his visit to Toronto in 1892, the advocates for a Canadian naval service

60 Johnston et al., The Seabound Coast, 124, citing Grey to Laurier 1 May 1908, Ottawa, Library and Archives Canada (hereafter, LAC), Wilfrid Laurier papers, MG 27 II B2, 3-291, 866. 
had been promoting him as a logical choice to organize and command the service, that the Admiralty supported the choice, and by no means least because Constance Kingsmill was working on both her husband and family connections in Ottawa, to influence their decisions. A series of cables and letters in the Kingsmill papers, dated from 8 to 20 May 1908, ${ }^{61}$ confirm what a strong connection there was between the Kingsmill family and the Liberal administration in Ottawa. On 8 May the minister of marine and fisheries wrote a personal letter, welcoming Kingsmill to the fold, observing:

for a long time I have cherished the hope of seeing a Canadian, possessing the necessary qualifications, acquired in the English Navy, take the command of our little Canadian fleet. I had naturally cast my eye on you in Quebec two years ago. Mrs Kingsmill, whom I had the

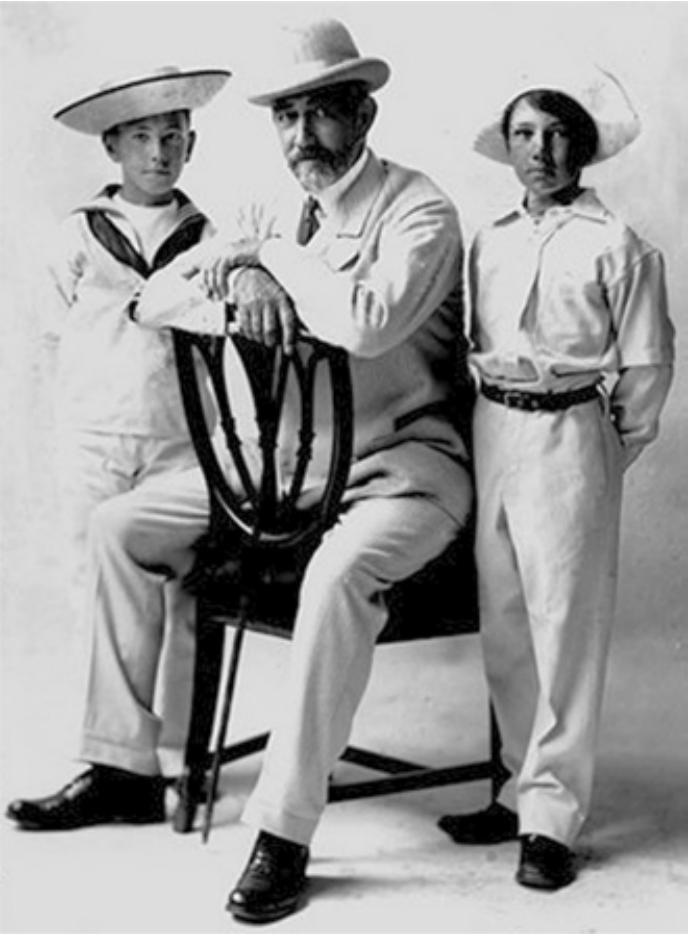

Illustration 4: Admiral Kingsmill with his sons Walter Juchereau and Charles Grange (always known as Grange) in Ottawa, c. 1910-14. pleasure of meeting at my house, one day gave me to understand that you would probably return to Canada, but I thought that was only the natural hope of a wife separated from her husband most of the time, and anxious to see him return home.

Constance Kingsmill's father, Walter Beardmore, was among the first to be told that the Canadian offer had been accepted. Brodeur's letter of 8 May to Kingsmill spells out the general scope of duties and responsibilities that he would be expected to assume. Referring to "an indiscretion which I have not been able to trace," he noted that the newspapers had learned of the appointment, one of "great public interest, and I am very glad of it." A few days later, on 14 May, Brodeur informed Mr Beardmore that "the Admiralty have recommended the appointment of Captain Kingsmill to the position of Commander of the Marine Service" and on 15 May Beardmore wrote to "My dear Charlie" enclosing the Brodeur letter, which included the paragraph: "As soon as Captain Kingsmill arrives in Toronto if I have not officially notified him before that, I shall expect him to proceed to Ottawa immediately. He will have a hard task on arriving here, because he will be called upon to organize our fleet for the Tercentenary Celebration in

61 L.P. Brodeur to C.E. Kingsmill, 8 May 1908; L.P. Brodeur to W.D. Beardmore, 14 May 1908 "private"; W.D. Beardmore to Kingsmill 15 May 1908; L.P. Brodeur to Kingsmill, telegram, 20 May 1908, Kingsmill papers, Brechin, Ontario. 
Quebec." Finally, on 20 May, Brodeur made everything official with his cable of congratulations for the promotion to rear-admiral, and stating "I am authorised by Governor in Council to offer you command of Canadian marine service."62

Kingsmill's subsequent career, summarised at the beginning of this paper, failed to fulfil the hopes that Laurier and Brodeur had given him. It was embarrassing to both Laurier and Kingsmill that on 30 July 1911 Niobe went aground during a summer cruise that was supposed to advertise, while the election campaign of that year was under way, the naval program envisaged by Laurier. The Conservative administration that came to power under Sir Robert Borden after the election was based on an alliance of disparate political groupings. "Having played partisan politics with the Canadian navy," observes the official history, " using both ends of the naval debate to undermine Laurier in order to help win the election, Robert Borden arrived in office with no coherent naval policy of his own." ${ }^{63}$ After the Senate defeated a House of Commons motion to repeal the Naval Service Act and replace it with the Naval Aid Bill, to finance new construction for the Royal Navy, Borden asked Kingsmill for suggestions. Kingsmill who, ironically, had been promoted vice-admiral on the RN's retired list on 17 May, observed "I have found it difficult, if not impossible, to prepare a memorandum on the subject." He argued in line with earlier Admiralty advice, for a modest force of torpedo boat and submarine flotillas, but the Admiralty under Winston Churchill reversed itself. The official history provides an accurate picture of the situation:

As the European powers drifted toward war in the summer of 1914, the Canadian naval service was largely incapable of acting as an "integral part of an imperial navy." The whole RCN consisted of fewer than 350 officers and ratings... While the differing naval policies of Laurier and Borden pointed to the philosophical distinction between their views of Canadian national development ... the basic question behind Canadian naval policy remained unanswered. Under Borden's leadership, Canada would enter the First World War having neither contributed dreadnoughts to an imperial fleet nor formed a proper naval service of her own. ${ }^{64}$

Over the next four years Kingsmill worked under enormous difficulties. $\mathrm{He}$ managed to keep a cool head, and improvised a totally inadequate force of vessels to meet the requirements of war. Niobe and Rainbow were placed under direct Admiralty control. As war broke out in Europe and the German light cruiser Leipzig posed a threat to the west coast, the Admiralty ordered Rainbow to "generally guard the trade routes north of the equator," an extraordinary idea for a cruiser with no modern ammunition and a wireless set whose range limited the ship to the vicinity of the Juan de Fuca Strait.

62 Johnston et al., The Seabound Coast, 124 cites a lack of documentary evidence concerning Kingsmill's appointment, but the preceding source material helps to fill that gap.

63 Ibid., 185-7. It should be noted that Borden had initially supported Laurier's concept for a Canadian naval force, ibid., 131-3. As Roger Sarty and Michael Hadley point out, Borden never did "waver from his long-standing conviction that gradual development of a smallwarship Canadian force was the only 'permanent policy' that could win widespread and enduring domestic support." Hadley and Sarty, Tin Pots, 61. 
Kingsmill's assessment of the risk led him to requisition the Grand Trunk steamship Prince George as a hospital ship ${ }^{65}$ no doubt less than hopeful about the results of a successful interception of the Leipzig. In the event, Leipzig departed the neighbourhood on the way to her eventual destruction at the Battle of the Falklands in December, 1914, and British naval reinforcements arrived on the west coast of Canada without further incident. ${ }^{66}$ Niobe on the east coast completed a long delayed completion of repairs to the damage suffered from her grounding in 1911, carried out various tasks under British Admiralty control until, worn out and unseaworthy, she reverted in September 1915 to RCN control, as a depot ship in Halifax. ${ }^{67}$

The official history sums up the problems Kingsmill now faced, in one paragraph:

Kingsmill would have little reason to alter his lament at the meagre resources with which the Royal Canadian Navy was being asked to undertake the nation's maritime defence. Despite Canada's willingness to recruit and maintain a four-division Canadian Corps on the battlefields of France and Belgium - one that would eventually gain a well-deserved reputation as one of the shock formations of the British Empire - the Borden government would never, in fact, provide the Canadian navy with the resources it needed "to carry out its responsibilities" to defend Canada's coastal waters during the First World War. With most of the government's wartime decisions on naval defence reflecting the inconsistent advice and empty promises Ottawa received from the British Admiralty in London, the remnants of Laurier's fledgling naval service would have to guard Canada's maritime interests with essentially the same motley collection of seconded civilian vessels that a dubious Kingsmill was forced to contemplate when he drew up a Canadian war plan... ${ }^{68}$

Canadian scholarship over the past twenty-five years has documented how Kingsmill and his minuscule staff in Ottawa struggled to provide adequate naval defences against ill-defined threats, mostly possible German submarine operations in the western Atlantic and the Gulf of St. Lawrence. Every effort to construct purpose built destroyers and submarines met stubborn resistance from a government informed by conflicting

65 "The nursing sisters appointed to the naval service on the Prince George were Elizabeth Pierce, Anne Dover, Gertrude Black, Penelope Mellen, Mabel Lindsey and Bessie Watson. The nurses were paid approximately $\$ 90$ per month. Their ship probably had the shortest life of any commissioned vessel in the RCN. Prince George was built in 1910. It was a 307 foot long steel vessel with twin screws, and weighed 3,372 tons"; John Webber, "First Aid: Nurses in the RCN, WWI", Canadian Forces base, Esquimalt, Naval and Military Museum, "Unsung Women". See also LAC, RG 24, vol. 882A, file HQ 51-212-16-3. This is a Militia and Defence file that suggests but does not state concern over the failure of the Department of the Naval Service to keep army authorities informed of affairs in Military District 11 (British Columbia). The ship served as a hospital ship from 12 August to no later than 9 September, when Dr. Stuart Tiley reported to the governor general that the ship had paid off. Johnston et al., The Seabound Coast, 254-256.

67 Ibid; Hadley and Sarty, Tin Pots, 126-7.

68 Johnston et al., The Seabound Coast, 215. 
advice from the Admiralty. ${ }^{69}$

They had also to oversee the shipment of vital war supplies across the Atlantic, done with the indispensable help of the Canadian Pacific Railway Company, and made arrangements to send Canadian volunteers for service with the $\mathrm{RN}$ and the Royal Naval Air Service, arrangements that left the RCN critically short of personnel when in 1917-18 German submarine operations placed shipping on western Atlantic sea lanes in danger. ${ }^{70}$ After vexatious negotiations with the Admiralty over the handling of telegraph communications, Kingsmill found ways to get vital traffic to Ottawa, and kept himself fully informed of RCN operations. Indeed, it has been suggested that he had a clearer view of convoy and escort deployments, when U-boat operations presented serious threats in 1917-18, than Captain Hose, captain of patrols in Halifax. ${ }^{71}$

The Halifax explosion of 6 December 1917 added to the difficulties Kingsmill had to deal with. Although he knew that the main culprits in this disaster were the Admiralty's shipping agents in New York who were loading merchant ships with dangerous combinations of explosives and flammables, "to the naval director's credit he kept his silence...and refused to point the finger of blame in the Admiralty's direction.", 72 And by war's end the shipping losses off the eastern seaboard, although very damaging to fishing fleets, remained negligible in defended convoys. ${ }^{73}$

Canadian and British naval authorities responded to the submarine threat by combining Canadian and United States naval and air forces assigned to the protection of shipping on the eastern seaboard. In April 1918 the commandant of the First Naval District in Boston and Kingsmill agreed on the allocation of responsibility to the USN as far east as Lockeport Nova Scotia "including the outer part of the Bay of Fundy," following which the USN took over the government wharf at Shelburne, Nova Scotia, as a base of operations. Aerial patrols, proposed as early as February 1917 and rejected at

69 Ibid., 361; Gimblett, "Forgotten Admiral"; Hadley and Sarty, Tin Pots, 123-5.

70 Johnston et al., The Seabound Coast, 375-383, 355, 622-630; S.F. Wise, Canadian Airmen and the First World War: The Official History of the Royal Canadian Air Force, Volume I (Toronto: University of Toronto Press in cooperation with the Department of National Defence, 1980), 603-608.

71 Johnston et al., The Seabound Coast, 443-4; William Johnston to Alec Douglas, 23 August 2013.

72 Johnston et al., The Seabound Coast, 505-532. "The views expressed by the Ottawa Evening Journal's editorial writers the 'the Canadian Naval Service...fell down' and had 'received a black eye' for its administration of Halifax Harbour were typical of the attitude held by many Canadians toward the fledgling RCN...This was especially true of Halifax, where the upstart RCN was often viewed as a contemptible usurper of the British navy's long-established role in the port...," ibid, 532. For a full account, including important material on Kingsmill's role, see John Griffith Armstrong, The Halifax Explosion and the Royal Canadian Navy: Inquiry and Intrigue (Vancouver: UBC Press, 2002).

73 Hadley and Sarty, Tin Pots, 200-203, 239-262, 278, 296-7. Hadley and Sarty quote Admiral Sir Herbert Richmond's minute of 22 November 1918: "There appear to be strong party differences of opinion on the Navy question in Canada and in consequence whole-hearted support for the Naval Administration is not available." 
that time by the Cabinet as too expensive, would have to be conducted by the USN from Halifax and Sydney until the Canadian Naval Air Service could be formed. In August 1918 Lieutenant Richard E. Byrd arrived in Halifax as "Officer-in-Charge, US Naval Air Forces in Canada." By the end of November this cordial period of joint operations concluded with Kingsmill's visit to Halifax and his farewell meeting with Lieutenant Byrd, who thanked him "for the dandy time you showed us on the yacht," and offered to help "should you continue your Naval Aviation as a peace time affair." 74

Promoted admiral on the Royal Navy's retired list on 3 April 1917, Kingsmill received several other marks of recognition for his war services. His efforts to support submarine construction at Montreal's Vickers shipyards in 1915, and the provision of escorts to sail them to England; the praise of Vice-Admiral Sir George Patey, C-in-C North America and West Indies Squadron for "readiness to give every assistance in his power" in 1916; the attention drawn by the Dominion government in November 1917 for the "services given by him and his staff during the war,", were all brought to the notice of the Admiralty. He was knighted by the King by letters patent on 6 February $1918 .^{75}$

In February 1919 Kingsmill, Georges Desbarats, (the deputy minister of the Department of the Naval Service) and Commodore Walter Hose ${ }^{76}$ formed

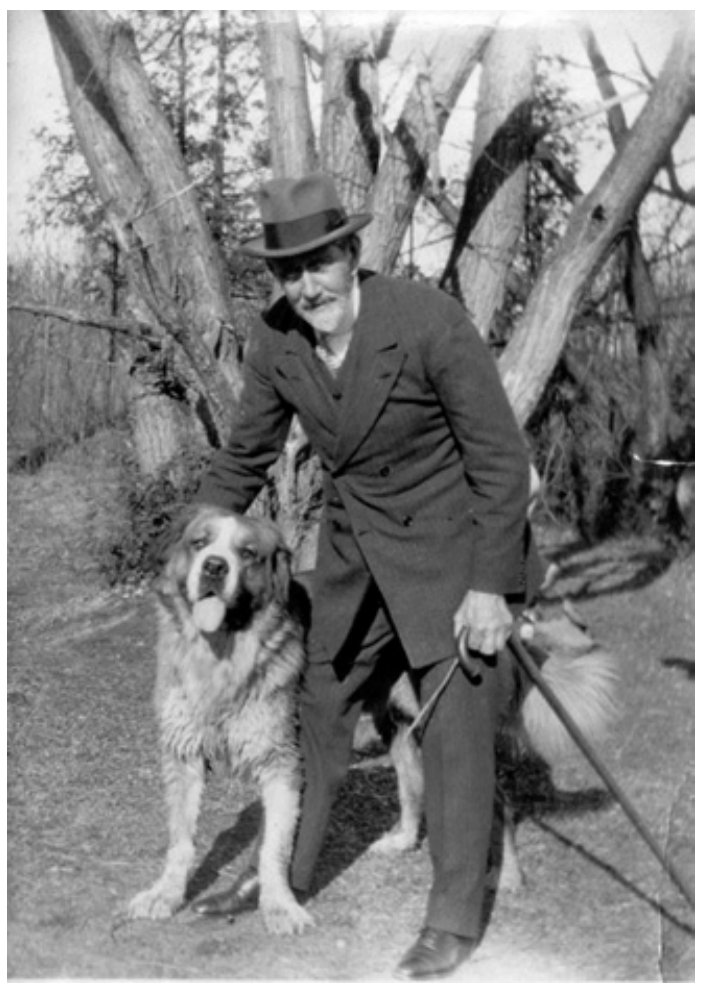

Illustration 5: Admiral Charles Kingsmill "and friend." (Courtesy the Kingsmill family.)

74 Johnston et al., The Seabound Coast, 571-2, 626-7; Roger Sarty, “The Origins of Canada-US Defence Cooperation: The Naval Defence of the Northwest Atlantic, 1914-18," in Briton C. Busch, ed., Canada and the great War: Western Front Association Papers (Montreal and Kingston: McGill-Queen's University Press, 2003), 131-43; Wise, Canadian Airmen and the First World War, 603-608; Byrd to Kingsmill, 30 November 1918, Kingsmill Papers, Phillipsville. Byrd of course went on to earn fame as a polar explorer.

75 TNA, ADM 196/38, p.755.

76 Commodore Walter Hose had been appointed captain of patrols in August 1917, the first RCN officer to hold the appointment, in place of Vice-Admiral Sir Charles Coke, RN (who had taken the appointment as a commodore RNR (retired) ) and in spite of the RN proposal to appoint another British officer as his replacement. Kingsmill persuaded the naval minister, C.C. Ballantyne, that the Admiralty could not appoint anyone to HMCS Niobe additional for charge of patrols because Niobe, now serving as a depot ship in Halifax, was 


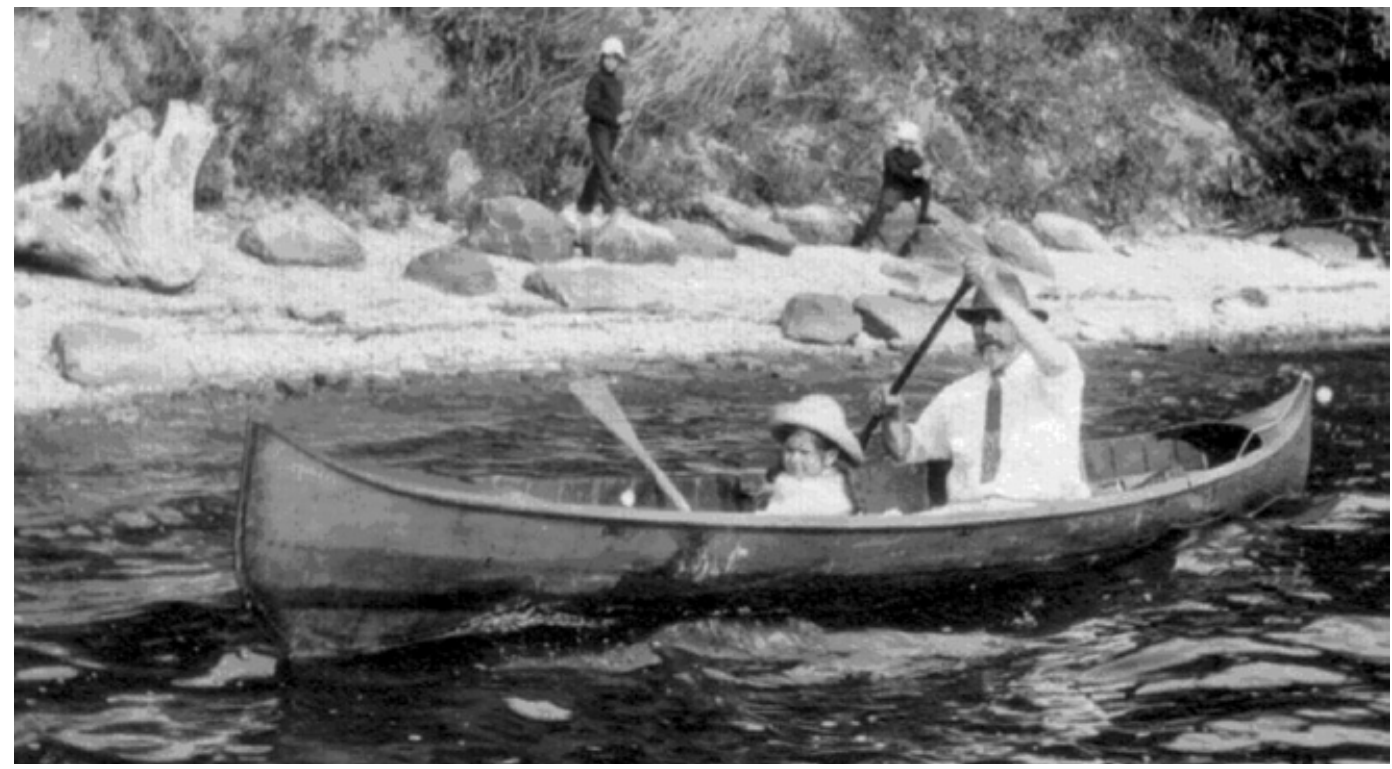

Illustration 6: Admiral Charles Kingsmill with his daughter Diana. (Courtesy the Kingsmill family.)

a naval committee to prepare recommendations for the future of the RCN. Under their direction the naval staff drew up thirty-six "occasional papers," partly based on the deliberations of an imperial war conference of 30 March 1917 requesting the Admiralty to "consider the most effective scheme of naval defence for the empire's security," but clearly influenced by the dominion prime minister's position that "proposals ... for a single navy ... under a central naval authority are not considered practicable." $" 77$ The so-called Jellicoe Mission, in which Admiral of the Fleet the $1^{\text {st }}$ Earl Jellicoe visited the dominions and India, resulted in a report that recommended fairly modest expansion of the $\mathrm{RCN}$, and a subsequent Cabinet recommendation in 1920 agreed on a reduced version of that proposal. When the Union caucus rejected the naval plan Borden, who at first proposed dismissing Kingsmill and most of the officials in the department, accepted Sir George Foster's advice for a compromise, deferring permanent navy policy for the time being, and to "carry on the Canadian Naval Service along pre-war lines." ${ }^{78}$ On the day Borden made that decision, 15

under complete Canadian control. In 1920 Hose would come to Ottawa as acting director of the naval service and naval assistant to the minister, Johnston et al., The Seabound Coast, 446-51,742-3.

77 Borden to Sir Eric Geddes (first lord of the admiralty), 15 August 1918, enclosure, Memorandum of the "Dominion Ministers," in A. Temple Patterson, ed., The Jellicoe Papers..., Volume II: 1916-1935 (London: Naval Records Society, 1968), $286-7$.

78 Foster to Borden, 25 March 1920, cited in James Eayrs, In Defence of Canada: From the Great War to the Great Depression (Toronto: University of Toronto Press, 1961), 164. Foster at that time was minister of trade and commerce, and a trusted adviser of Borden. 
March 1920, Kingsmill submitted his resignation, with effect on 31 December $1920 .^{79}$

When Charles Kingsmill accepted Prime Minister Laurier's invitation to transform Canada's marine and fisheries department into a naval service, there was no immediate threat of war. When war did come, the direction he received, both from the Admiralty and his own government, was literally to make bricks without straw. ${ }^{80}$ In the end, he did just that. And as the official history has observed, he may have suffered terrible disappointments before and after retirement, but he seems to have held no grievances. Sir Robert Borden recalled that in the summer of 1920 he visited Kingsmill at his retirement home on Grindstone Island and considered it one of several "delightful visits with friends." ${ }^{81}$ No doubt Sir Charles' grandfather, Colonel William Kingsmill, would have approved.

79 He resigned without regret, except for one thing: "This will about finish up anything I can do for the College. It is the only part of the Naval Service that I regret ceasing to have anything to do with." Kingsmill to Commander E.A. Nixon, Commandant of the Royal Naval College of Canada, 7 April 1920, Commander E.A.E. Nixon Papers, DHH 74/689, folder C “19201921 ," file 50.

80 "And the taskmasters of the people went out, and their officers, and they spake to the people, saying, fulfil your works, your daily tasks, as when there was straw..." Exodus 5, 13.

81 Johnston, et al., The Seabound Coast, 742, citing Henry Borden, ed., Robert Laird Borden: His Memoirs (Toronto, 1938) II, 1042 
